\title{
Main Principles of the Strategy of Socioeconomic Development of the Northern and Arctic Regions of the Krasnoyarsk Territory (Krai)
}

\author{
Anatolii G. Tsykalova, Ruslan V. Goncharov ${ }^{\mathrm{b}}$, \\ Natalia P. Koptsevac, Aleksandr N. Pelyasov d,e, \\ Aleksandra V. Poturaeva ${ }^{\mathrm{d}, \mathrm{e}}$ and Nadezhda Yu.Zamiatina ${ }^{\mathrm{d}, \mathrm{e} *}$ \\ ${ }^{a}$ Government of the Krasnoyarsk Territory (Krai) \\ Krasnoyarsk, Russian Federation \\ ${ }^{b}$ National Research University Higher School of Economics \\ Moscow, Russian Federation \\ 'Siberian Federal University \\ Krasnoyarsk, Russian Federation \\ ${ }^{d}$ Institute of Regional Consulting \\ Moscow, Russian Federation \\ ${ }^{e}$ Lomonosov Moscow State University \\ Moscow, Russian Federation
}

Received 10.03.2020, received in revised form 30.04.2020, accepted 12.05.2020

\begin{abstract}
The article reflects the main features of the new Strategy for Socioeconomic Development of the Northern and Arctic Regions of the Krasnoyarsk Territory of Russia. The work employs standard methodological tools for the development of the regional strategic documents, such as assessment of the situation, general principles of the socioeconomic development of the Northern and Arctic regions, characteristics of the main tools and expected results of the strategy, and spatial planning issues. The new policy is aimed to soften development contrasts between the Northern and Arctic municipalities of Krasnoyarsk krai. Big expectations are associated with the introduction of innovations in the delivery of the critical services and products to the remote towns and settlements of the area. The main methodological innovation applied in the Strategy is the establishment of three project offices working on the problem on three large-scale levels. These are the "Person", "Settlement" and "Territory" project offices. Their tasks involve ensuring synergy between the government, large and small businesses, and social bodies. It is assumed that in the year 2030 the implementation of the proposed measures will enable the Krasnoyarsk Territory to regain its leading position in the development of the Russian Arctic it used to hold during the first decades of the Soviet period.
\end{abstract}

\footnotetext{
(C) Siberian Federal University. All rights reserved

* Corresponding author E-mail address: decanka@mail.ru, nadezam@yandex.ru ORCID: 0000-0003-3910-7991 (Koptseva); 0000-0002-4941-9027 (Zamiatina)
} 
Keywords: economic development, North and Arctic territories of the Krasnoyarsk krai, innovative system, project offices.

Research area: culturology.

Citation: Tsykalov, A.G., Goncharov, R.V., Koptseva, N.P., Pelyasov, A.N., Poturaeva, A.V., Zamiatina, N.Yu. (2020). Main principles of the strategy of socioeconomic development of the Northern and Arctic regions of the Krasnoyarsk Territory (Krai). J. Sib. Fed. Univ. Humanit. Soc. Sci., 13(5), 800-817. DOI: 10.17516/1997-1370-0608.

\section{Introduction}

There is no other territory in the Russian North so gifted with natural resources and rich in picturesque landscapes, unique ethnical and exploration traditions as Krasnoyarsk krai (Korytnyy, Tulukhonov, 2016; Shadrin, Larionova, 2019; Koptseva, 2017, et al.)

But how can all these enormous spaces of the Krasnoyarsk "spontaneous" tundra and taiga be tamed? This is one of the challenges the Russian state has always been facing; during the Soviet time, a lot had been done (Slavin, 1961; Kosmachev, 1974; Sartakov, 1985; Malov, 2014).

The Krasnoyarsk Territory (Krai) has accumulated a vast experience of supporting the indigenous people in different historical periods of transition to a new technological and socioeconomic stage. From here the basics of the governmental national policy had been elaborated and tested to be later implemented in the other territories of the Russian North. The Northern regions of the Krasnoyarsk Territory had always (since the 1930-s) been the pioneers in the development of the industrial transport infrastructure of the North and the Arctic; krai had been the outpost of exploration of the circumpolar zone of the Arctic Ocean (since the 1960 -s) and the development base for the Eastern sector of the Northern Sea Route (since the 1960-s).

In the last 25 years, however, the government seems to have frozen its active and conscious transformation efforts to replace them with the invisible hand of the market. It had led to some dramatic, if not to say tragic consequences. The internal contrasts between the areas of relative prosperity and depression, unprecedented for the global North, had come up. The short-term experiment of establishing the Evenkia and Taymyr autonomous okrugs failed to fulfil the great expectations associated with it. All the attempts to reverse the situation were unsuccessful, though the hope for a miracle, which in the North of the region is always associated with the new mineral extraction megaprojects, would still appear now and then.

But what are the ways of raising the living standards of the residents of the North and the Arctic, how can the "disparity of rights" compared to the South of the region be overcome? How can the limitless territories of the North and the Arctic areas of the Krasnoyarsk Territory be covered with the Internet connection and proper cost-effective and efficient transport infrastructure? And finally, how can we make the indigenous peoples of these territories, the Russian old-timers and the local ethnicities, feel the government support without getting paternalistic and overprotective, how can we encourage their self-development, how can we make them feel like hosts, not the outcasts in their own land?

The Krasnoyarsk Territory has everything to start the process of positive transformations in the North and the Arctic: the power and will of the governor's team relying upon the legendary traditions of the pioneer exploration of the Soviet Transpolar territories, the strong Russian corporations that established their presence in the region long ago, the patriotism of the local people who have always valued this land as their home.

The Krasnoyarsk Territory was the first of the Arctic and Northern territories of Russia to articulately announce the revival of the active governmental policy for the development of the North after almost three decades of dominating market self-regulation in the scarcely populated, remote territories with severe cli- 
mate. Just like in the 1930-s, when the region became the first to deploy the Soviet Northern industrialization project, after over 80 years the Krasnoyarsk Territory is ready to take up responsible leadership in getting the federal and regional authorities personally involved in the development of these strategically significant areas, from the local social paternalism to the proactive strategic partnership with the large and small businesses located in the North and the Arctic. This is the first time when new principles of partnership and smart direct participation of the government in the exploration of the Arctic and the North, of the stimulation of introducing new solutions into the development and social evolution will be developed here to be spread later over the other territories of the Russian Arctic and the North.

\section{Analysis of the situation}

The most important result of the socioeconomic development of the Krasnoyarsk North and the Arctic of the last three decades was the unprecedented aggravation of the internal contrasts. On one hand, there are the prosperous "corporate" territories of the Norilsk industrial district, the new rotation production camps, with the per capita revenue exceeding the average for the region. With the efforts of the major resource companies focused on the generation of new and modernization of the old assets, implementation of the corporate social responsibility programmes, the accumulated economic and social potential of the area can never be exhausted.

On the other hand, there are depressive areas and spots with the actual revenues and the social infrastructure quality below the average for the region, with the continuous outflow and marginalization of the remaining population forced to make their living with illegal activities. Compared to the formal improvement of the housing and social infrastructure per capita, these areas are experiencing extreme deterioration or even destruction of the previously accumulated social and economic potential, the loss of the economic specialization and rapid ageing of the remaining population. Together with the reduction of the permanent population by over one and a half times since the year
1990, the number of rotation workers employed at the new and old mineral extraction projects is dramatically increasing. The segregation into the progressive and depressive poles is typical for the Krasnoyarsk North and Arctic territories more than for any other northern areas in the world.

The key feature of the socioeconomic situation in the Northern and Arctic municipal entities of the Krasnoyarsk Territory is a slow, but consistent reduction of the population. All around the territory, the only city experiencing population growth in the last eight years is Norilsk.

Comparison of the population growth dynamics in the districts and municipalities belonging to the Arctic Zone of the Russian Federation (AZRF) to that of the other northern territories reveals apparent stability of the Krasnoyarsk Arctic and depopulation of the North (Fig. 1).

Comparison of the current condition and the last decades' development trends of the Krasnoyarsk North and Arctic regions to that of the other circumpolar areas reveals huge diversity of natural resources (attracting the ore, oil, gas, coal mining companies and wood corporations - see Fig. 2), the extreme complexity of the previous economic exploration cycles (with the first one beginning one century ago and the latest one starting only several years ago), the colossal habitats of wild flora and fauna and virgin nature in the northernmost land of the world and, at the same time, a great number of accumulated problems (Maklakov, Malygina, 2016; Gosudarstvennyy doklad..., 2017; Semenova, Popel'nitskaia, 2017, et al.).

The scope of the development problems faced by the Northern and Arctic regions of the Krasnoyarsk Territory together with their great resource and human potential require an active government regional policy to be formulated.

\section{New regional policy for the Northern and Arctic development}

The strategic objective of the socioeconomic development of the Northern and Arctic regions and the ethnodynamics of the small-numbered indigenous peoples of the Krasnoyarsk Territory in the nearest years is to 


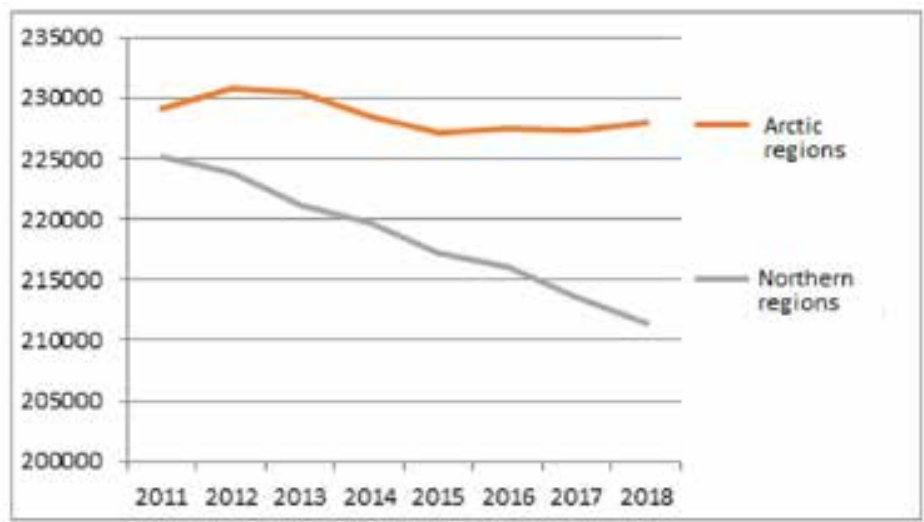

Fig. 1. Dynamics of the population rate in the Northern and Arctic regions of the Krasnoyarsk Territory, persons

(Krasnoyarskstat: Database of indicators of municipalities)
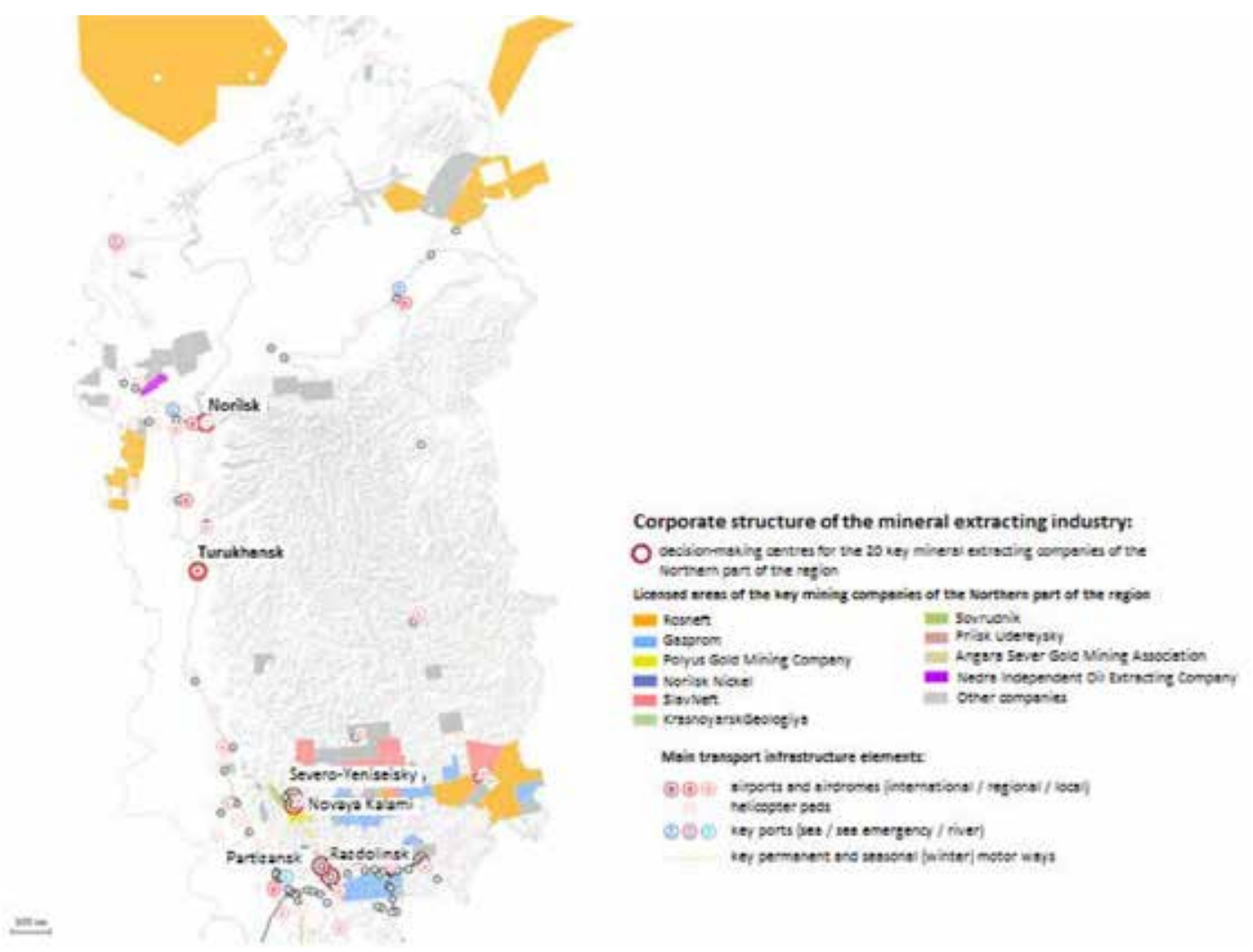

Fig. 2. Main resource extracting projects of the Northern and Arctic regions of the Krasnoyarsk Territory

ensure the maximum deployment of the regional potential to unleash the personal potential of every permanent or temporary resident of the area. This objective had established the princi- ples, priorities, and approaches of the previous regional policies.

The new system of principles and priorities of the regional policy concerning the Northern 
and Arctic regions of the Krasnoyarsk Territory is based on the reassessment of the internal potential of the territory. New understanding of the regional development process underlies such regional policy principles as innovation, proactivity, and responsibility.

Implementation of the innovation principle in the regional policy means universal involvement of the latest achievements into increasing the efficiency of the economy in the North and the Arctic, into the improvement of energy and food security through the introduction of new energy-efficient technologies and specialized Arctic agricultural technologies, the latest teaching methods and education forms, new public healthcare methods, and large-scale digitalization of the Northern economy.

Introduction of the proactivity principle in the regional policy means providing maximum support to the local initiatives facilitating the economic stability of the Northern settlements, their energy and food security, improving the comfort of their habitat and self-fulfilment opportunities. It requires both withdrawal of the excessive statutory and institutional regulations holding back the social initiatives, and establishment of a new system of actions for the consistent development of the creative skills of the population, support and development of the local social initiatives and entrepreneurship.

Implementation of the responsible development principle envisages alignment of the interests of all the actors and future generations of the Northern and Arctic residents, including:

- development of the transparent economic management principles requiring, on one hand, general withdrawal of the excessive and outdated statutory regulations, and, on the other hand, a transparent and efficient system for enforcement of the current norms and regulations;

- development of an efficient system of interaction between the regional development parties (including large resource extracting corporations, small businesses, federal and municipal authority bodies, associations of the small-numbered indigenous peoples of the North and other social organizations);

- comprehensive development of the competences of the Northern and Arctic pop- ulation including small-numbered indigenous peoples to improve their entrepreneurial capacities, encourage their involvement in the current value chains of production and sales of the environmentally-friendly products manufactured with the renewable resources of the North and the Arctic, and implementation of the best practices of economic management, life support and environmental security in the conditions of the Northern and Arctic territories, as well as introduction of the health-saving technologies and effective local self-government.

Consistent implementation of the innovative, proactive and responsible development principles in the Northern and Arctic regions of the Krasnoyarsk Territory will:

- ensure the activation of the industrial exploration of the North and Arctic regions by introducing transparent economic management regulations, popularization of the effective forms of activity organization and support as well as the modern digital technologies;

- multiply the development effect of the Krasnoyarsk Territory by involving the industrial enterprises of the southern territories of the Territory and other entities of Russia into the exploration of the North and Arctic territories, including the defence facilities conversion programmes;

- increase the overall effectiveness of the Northern economy through broad development of the civilized rational forms of exploitation of the replenishable natural resources, arrangement of the marketing and sales channels and promotion of the environmentally friendly products manufactured in the Northern and Arctic districts of the region;

- increase the sustainability of the Northern settlements by reducing their dependence on the costly fuel transportation and material-intensive structures and equipment, improving the telecommunication coverage, leveraging the food security level by introducing the latest agricultural industry achievements in the Arctic farming;

- enhance the security of life in the Northern and Arctic regions, facilitating the fulfilment of the population protection task by spreading modern medical assistance practices and introducing health-saving technologies; 
- facilitate the conservation of the natural resources and traditional culture of the Northern and Arctic districts of the Krasnoyarsk Territory for the future generations.

Introduction of the modern principles of development of the Northern and Arctic territories based on universal fulfilment of their potential requires the implementation of the following regional policy priorities:

- ICT: ensure the large-scale distribution of the modern communication and connection technologies in the Northern and Arctic regions of the Territory to ensure further digitalization of the local economy and the social sphere;

- keeping warm: load the provision systems of the Northern and Arctic regions with fuel and food (increasing the energy and food security of the Northern settlements), ensure the environmentally friendly industrial development, development of the innovative technologies for providing environmental sustainability of the industries and support of life in the Northern and Arctic settlements;

- self-development: maximum withdrawal of the administrative barriers holding back and hindering the solution of the current issues of socioeconomic development and transport infrastructure in the remote settlements; comprehensive support of the local initiatives focused on the improvement of the sustainability of such settlements (including proposals of amendments into the Federal Law on self-government to account for the specific local self-government development conditions of the Arctic and the Extreme North);

- non-drinking (healthy) North: universal introduction of the modern population preservation practices in the Northern and Arctic conditions based on the foreign and Russian experience;

- new culture: development of a new system to support and promote the cultures of the ethnicities populating the Northern and Arctic regions (including digital technologies); positioning the Krasnoyarsk Territory as the major cinema centre and the capital of the Arctic;

- rules of the game (coming out of the shadow): development of transparent rules for the exploitation of the replenishable natural resources and proper control over their enforcement.

To achieve the objectives of the socioeconomic development of the Northern regions of the Krasnoyarsk Territory determined by both the development of the new branches and spheres of economy, promotion of new technologies, and the withdrawal of the outdated obstacles from the way of socioeconomic development, it requires the coordinated effort of many parties, such as administrations of various levels, experts, businesses and local communities. To raise the bar of our achievements, we suggest supporting the currently existing governmental Northern policy bodies with the three new project offices to ensure the coordination of efforts and balance of resources between different parties of the socioeconomic development: person - dignity; settlement sustainability; territory - accessibility.

The profile focus of the project offices is based on the tasks set by the national projects and strategic socioeconomic development objectives of the Russian Federation, the Arctic Zone of the Russian Federation, the Krasnoyarsk Territory and the most complex socioeconomic development problems of the Northern and Arctic regions of the Krasnoyarsk Territory themselves, such as protection of the population, the life support efficiency, enhancement of the economic base of the Northern and Arctic regions of the Krasnoyarsk Territory as a whole. The absolute majority of the measures taken by each project office are intended to raise the living standards of all the residents of the Northern and Arctic regions of the Krasnoyarsk Territory with no exceptions, including the indigenous peoples.

The project office deployment consists of five stages: 1) starting up the activity organization (before the end of 2019); 2) diagnostics of the current situation (2020); 3) development of the new means and methods of development (2021); 4) testing the development methods at the pilot platforms (2022); 5) applying the pilot platform experience to other areas (2023-2025).

Person - Dignity Project Office. The objective of the project office is the comprehensive development of the human capital and 
establishment of decent accommodation for the people, improving the accessibility of the required qualified services. The main condition for achievement of the set objectives is to ensure fast and direct delivery of high-quality service to every person resident in the territory of the North and the Arctic of the Krasnoyarsk Territory without intermediators. The key tasks of the project office include diagnostics of the people's needs; selection of the living standards' improvement measures; optimization of the existing service delivery procedures and conditions. Due to the scarce population and widely-spread nomadic lifestyle, the services should be delivered using modern (innovative) information and telecommunication technologies.

The office will search for the best solutions in the following key areas: telemedicine and long-distance education development; technical equipment of the air medical service and removal of the institutional barriers for the use of the medical aircrafts; development of the medical self-diagnostic systems; development of the long-distance public environment monitoring and long-distance consulting system; digitalization of the small-numbered indigenous people's (SNIP) culture in the digital space by creating digital archives, digital textbooks, keyboards for communication in their ethnic tongues using SMS and Internet messengers; review of the trade and exchange relations between businesses and the SNIP.

Settlement - Sustainability Project Office. The objective of the project office is to ensure sustainable development of the Northern and Arctic settlements of the Krasnoyarsk Territory by improving their food and energy security and arrangement of comfortable housing conditions. The objective will be achieved by implementing innovative management technologies and the optimization of the settlement service delivery schemes.

The key tasks of the project office include the diagnostics of the settlements from the perspective of food and energy security, the level of comfort, accumulation of the best Russian and modern practices of economic management in the Northern and Arctic conditions; development of a set of measures for different types of settlements depending on the situation and their improvement potential; implementation of the "people's innovators" institution to simplify the introduction of new technologies and techniques; analysis and optimization of the settlement supply and service procedures; testing and optimization of the self-sufficiency improvement measures of the Northern settlements.

It is suggested to establish demonstration platforms at the transport network hubs: Vorogovo/Yartsevo, Motygino, Igarka, Potapovo, Tukhard, Khatanga, as well as in Volochanka which has already accumulated some positive experience of local initiative implementation. A competition will be held to select responsible users of the demo samples of the innovative technologies and devices as the "people's innovators", entitled to additional financial and/or technical assistance, expanded training opportunities etc., who will get demo samples of the technologies at their disposal and will get regular information support. Social sphere innovation centres will be established. The centres will be equiped with the necessary demonstration equipment, training platforms and experimental polygons.

The best practices will be accumulated and the sets of necessary measures will be developed in the following areas: improvement of the self-sufficiency of the population (substitution of the imported groceries and energy sources) by settlements; optimization of the infrastructure and improvement of the public amenities in the settlements; optimization of the supply and service of the settlements (logistics, contingency prevention etc.).

The social innovation centres will provide demo samples of buildings and structures to be tested by the population ( "demonstration quarter" and "demonstration house"); training sessions and new technology presentations will be provided; reports of the informal local leaders, specialists of the housing and utilities' sector, and local self-government bodies on the implementation of the new technologies will be made.

Territory - Accessibility Project Office. The objective of this project office is the comprehensive implementation of the economic 
potential of the Northern regions of the Krasnoyarsk Territory using an efficient distribution system for goods and services. The main tasks of the office are the analysis of the transport and logistic roadmaps, natural, mineral and touristic potential of the territory, the opportunities, restrictions and risks of its implementation; accumulation of the best Russian and foreign practices of nature use, processing industries, tour organization, transportation and logistics in the Northern and Arctic conditions; development and implementation of an efficient system of nature use, production and distribution of goods and services.

The pilot platforms will be arranged in the settlements with the preconditions for "sustainable traditional economy management" (Tukhard, Baykit, Yartsevo, Khatanga etc.) owing to their high economic potential (facilities for the production of competitive goods and services; ethnic tourism, environmentally friendly agriculture and fishery, herb picking etc.). These settlements will be the key elements in the economic development of the surrounding territory, hubs in the traffic of goods and services.

In cooperation with the responsible body in charge, the executive authorities of the Krasnoyarsk Territory will develop a rewarding system for the budgetary institutions' employees contributing to the work of the project office and their initiatives in the project implementation. Another encouragement system will be arranged for businesses; possibility and rationality of applying public-private partnership will be also considered.

\section{Spatial development and growth areas of the North and the Arctic regions in the Krasnoyarsk Territory}

All the measures taken under the new regional policy of the region in the vast territories of the Arctic and the North need to be territorially differentiated to ensure their effectiveness and efficiency. According to the experts, the greatest impact on the spatial differentiation of the socioeconomic development of the North and Arctic regions of the Krasnoyarsk Territory is caused by the two key factors: the transport accessibility and location of the large mineral resources production areas. By the combination of such factors, the Northern and Arctic areas of the Krasnoyarsk Territory can be classified into six main types that the regional policy measures shall be adjusted to (see Fig. 3).

Types of regions outside the zones of industrial exploration projects:

1. The most explored areas of the southernmost regions of the North: the Yeniseisky, Motyginsky, Boguchansky, Kezhemsky and Severo-Yeniseisky Districts accessible by transport all year round; this is where the major cities and settlements including Yeniseisk and Lesosibirsk are located. The south of the northern area of the Krasnoyarsk Territory is the "outpost", the exploration base for the more remote and less accessible areas, which determines its economic specialization. It makes them strengthen their function as a logistic, technological and HR base for the exploration of the remote northern areas. The local roads need to be improved (particularly, in the Kezhemsky District) to increase the transportation speed and to reduce the transport maintenance costs. The growth areas here are interregional socioeconomic development facilities.

2. Coastal areas of the major rivers and the Northern Sea Route region accessible by large water cargo carriers. The typical settlements are Bor, Vorogovo, Turukhansk, Potapovo, Karaul etc. The main measures to be taken are related to the connection with other settlements (quay facilities, number of flights etc.). The growth areas for this type of regions are local innovation centres, local information and logistic bases, etc.

3. Impassable areas accessible by seasonal motor transportation (mostly, on winter roads), less by rivers and by air. These are the most problematic territories of the Krasnoyarsk North, requiring the urgent implementation of the new and cost-efficient technologies of life support, people preservation, new marketing solutions in the transport organization and the distribution of the traditional products, as well as improvement of the living standards.

On the Taymyr Peninsula, it is reasonable to build a winter power station network; in the southern regions, it makes more sense to use 

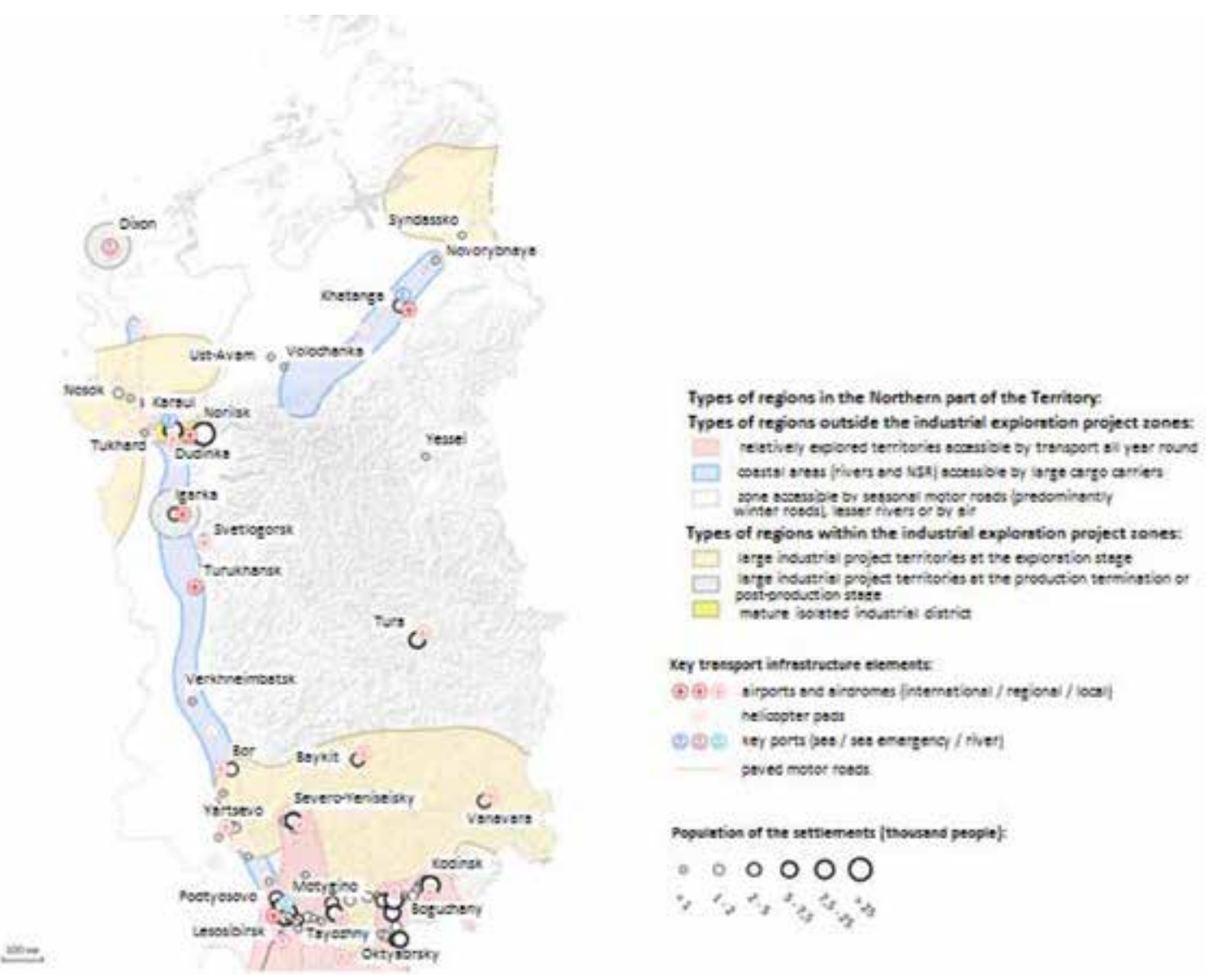

Fig. 3. Main types of the Northern and Arctic regions of the Krasnoyarsk Territory

turf (such as in Yartsevo village of the Yeniseisky District) or micro-hydropower stations (such as on the Ket river of the Yeniseisky District, the Taseevka river of the Motyginsky District etc.). An important economic factor for the development of these territories would be a reformation of the government use system (concerning the organization of transparent procedures for the catch or collection, certification, transportation and distribution of the reindeer breeding, hunting, fishery, wild herb products).

The settlements standing on the domestic water lines, first of all, bearing the administrative status of the municipal district and settlement centres, will be considered as the potential starting points (growth poles) for the implementation of the innovative technologies to improve the life of the population and the sustainability of the northern economy.
Growth areas here are local innovation centres, local information and logistics bases.

Types of regions within the zones of industrial exploration projects:

4. Territories of the large industrial projects at the exploration stage are: the large-scale oil production districts, such as the Vankor Oil Production Cluster or the Vankor Field Group of Rosneft Oil Company, PJSC (the Vankor, Suzun and the adjacent oilfields) in the Turukhansky District of the Territory; the Yurubcheno-Takhomskoe oilfields and, potentially, the Eastern Taymyr (the Khatanga block) oil production districts; the large gold-mining district in the Severo-Yeniseisky District (Olimpiadinskoe and the adjacent deposits developed by Polyus company); the new forest development areas in the Boguchansky and Kezhemsky Districts; potentially, the coal mining district near Dikson settlement, development of the new oil 
and gas deposit in the Trans-Angara area etc. They require close interaction with the communities and administrations of the municipal entities (public-private and municipal-private partnership in the spheres of transport, energy, and other infrastructures, food supply orders, such as supplies of fish for the company staff etc.). The main growth areas here are associated with the implementation of large infrastructure projects.

5. Territories in the surroundings of the large industrial projects at the final production or the post-production stage, such as Igarka, Dikson, old Motyginsky and other forest industry districts (area of the settlements eliminated in the 1960-1980-s), These areas are the most problematic from the socioeconomic development perspective. These are the districts that were the first to be explored (1930-1960s), featuring a well-developed infrastructure, old-timer population (some families have lived in the settlements for three generations; therefore, they have adjusted to the severe climate, developed perfect Arctic survival skills etc. and have a strong emotional bond with their place of residence) and rich cultural heritage.

For such old industrial districts and settlements, the sanitation mechanism needs to be thoroughly discussed (with the possible options of closing or compression of the settlements to improve the living standards of the remaining population, changing the profile based on the new logistic or cultural and touristic projects). Besides new specialization, the old industrial districts require a lot of efforts for the improvement of housing, maintenance of utilities, as well as sociocultural work with the local population. The growth areas here are associated with local innovation centres, local information and logistics bases.

6. Mature isolated industrial district. This type is represented by the unique Norilsk industrial district, which combines the problems of the younger resource areas and the old industrial territories. It features a high wear level of the housing and utilities infrastructure like an old industrial district, but, at the same time, suffers from the extensive environmental problems (excessive content of sulphur dioxide and other harmful substances in the atmospheric air) and the recent migrants' assimilation challenges like a new resource project territory. The perspectives of the area are associated with the completion and development of not only the industrial but the socioeconomic functions of the surrounding territories (scientific, innovative, cultural, medical, educational, trading, construction centre of the entire Taymyr District), which would be impossible without a stable transport connection between Norilsk and other settlements of the Taymyr Peninsula.

Today it is a universally recognized fact that in the innovative economy the main economic growth drivers are determined by not as much by the large resource and infrastructural projects implemented (such growth is often limited by the deposit exploration time), as by the internal, endogenous factors of the local economic and institutional environment ensuring the continuous production and implementation of innovations and flexible response to the changing economic development conditions, as well as in the peripheric northern areas (Audretsch, Thurik, 2001; Hausmann, Rodrik, 2002; Herrschell, 2012; Huskey, 1987; Rodrik, 2004; Taylor et al., 2016; Petrov et al., 2017; Zamiatina, Pelyasov, 2013; Pelyasov, 2017).

With the diversity of conditions in the North and Arctic areas of the Krasnoyarsk Territory in mind, the Strategy points out several types of growth areas, from the new large-scale mineral extraction projects accompanied with a large infrastructure construction campaign to the new-type growth areas being the "gateway" for implementation of the innovations in the remote territories, ensuring the growth by boosting the quality of the local business environment and the conditions for its development (Table 1). In the short run, the most prominent economic growth areas are the new large-scale resource project implementation zones (the fourth type of the Northern and Arctic regions of the Krasnoyarsk Territory).

The infrastructural growth areas coincide with the districts where new resource projects are being implemented (mainly the new oil and gas fields or gold deposit exploration areas). They require the promotion of public-private partnership to arrange the use of the infrastructural objects by the corporate customers, local 
Anatolii G. Tsykalov, Ruslan V. Goncharov... Main Principles of the Strategy of Socioeconomic Development...

Table 1. Differentiating the growth areas by the socioeconomic development types of the Northern and Arctic regions

\begin{tabular}{|l|l|}
\hline \multicolumn{1}{|c|}{ Types of territories } & \multicolumn{1}{c|}{ Growth area types } \\
\hline Relatively explored zones & Interregional comprehensive socioeconomic development base \\
\hline Coastal zones & Local innovation centres, local information and logistics bases \\
\hline Impassability zones & Local innovation centres, local information and logistics bases \\
\hline New resource project zones & Infrastructural growth areas \\
\hline Old northern industrial territories & Local innovation centres, local information and logistics bases \\
\hline Isolated mature industrial district & Interregional comprehensive socioeconomic development base \\
\hline
\end{tabular}

population and entrepreneurs to improve the living standards and the economic sustainability of the settlements located in the mineral field exploration areas. The use of different transport passageways by the vehicles of proper capacity shall be strictly regulated (to prevent the heavy trucks from moving on the unprepared roads or to ensure adequate compensation).

In the coastal areas and the impassability zones, as well as in the old industrial northern regions (types 2, 3 and 5) the innovation spreading points will be developed for the enhancement of the energy and food security together with the new people-saving technologies. These will be the pilot platforms established for the project offices.

Moreover, to strengthen the economic base of the Northern and Arctic regions in the major settlements with an advantageous location (e.g. Khatanga, Dikson, Potapovo, Tukhard, Turukhansk, Motygino, Boguchany, Tura, Baykit etc.), local information and logistic bases will be organized to ensure the efficient collection and, if necessary, storage, primary processing and transportation of the northern products (reindeer breeding, fishery, wild herb products, traditional crafts etc.) as the measures taken by the Territory - Accessibility project office. Such places will serve as the focus of economic activity of the Northern and Arctic territories in the sphere of concentration and re-distribution of the traditional economy products.

The old industrial territories and, first of all, the major old industrial centre Igarka which is currently in a critical condition, require some dramatic changes. Based on the experience of the foreign northern old industrial centres, the functions of the city will be reassessed; the image of the industrial centre in a crisis condition will be replaced with that of a logistic centre, a scientific and information base for the Yenisei North exploration.

In this regard, Igarka still has a certain potential, as in the past it used to be more than just an important transport hub, but, just like Norilsk, it also was the "information exploration" base, a centre of scientific research ensuring the sustainability of the economic activities in the Extreme North (geological surveys, cryolithology studies, agriculture etc.), the agricultural production centre (vegetables, dairy), an important SNIP education centre (Igarka used to have a school which was the "forefather" of the Taymyr College transferred to Dudinka in 1998. Today, Igarka is more than just a transfer hub for the Vankor field; to a certain extent the city acts as the economic, social (medical service) and HR base for Svetlogorsk; this is a museum centre and a practice polygon for the cryolithology students; the education function of the area is partially supported by the Igarka College. A consistent restoration of Igarka as a part of the new Norilsk cluster with the new technological base as an Arctic agriculture polygon and a powerful museum and tourism centre (as well as a base for the scientific, expedition and education activities), the improvement of the local medical base, expansion of the education facilities would mitigate the depressive condition of Igarka and facilitate the development of the Northern and Arctic districts of the Territory as a whole (through the development of 
tourism, culture, food security, education and medical services).

The sustainable development of all the Northern and Arctic regions of the Territory will depend on the expansion and development of the functions of the major cities as comprehensive interregional development bases. The subject matter here is the Norilsk Industrial District, Yeniseisk-Lesosibirsk agglomeration and, perhaps, a similar base that may grow around Kodinsk and Boguchany. As for service functions provided to the surrounding territories, the scientific, educational, medical and cultural institutions, the core touristic facilities and services have partially lost their potential and remain partially underdeveloped.

The most dramatic situation is found in Norilsk which shows the potential of development not only as a specialized industrial centre but also as a true socioeconomic development centre of Taymyr, its scientific and educational, innovative and sociocultural flagship. The breakthrough development of the Taymyr Peninsula, the Turukhansky District and partially the north of Evenkia is only possible through the reassessment of the role played by Norilsk in this territory.

Paradoxically, at the end of the Soviet period, Norilsk was close to the role of such a comprehensive economic centre more than ever, when it concentrated all the scientific studies in the spheres of geology, construction, polar medicine, Arctic agriculture, development and testing of the construction technologies adjusted for the permafrost conditions. Norilsk also acted as a training centre for the workers of culture including traditional art (Norilsk Art College). Many of these functions have faded or even disappeared during the decades following the privatization of the local backbone enterprise (currently, Norilsk Nickel Mining Company).

But even today, modern Norilsk seems to be unwillingly concentrating many functions of providing services to the surrounding territories; this is an important centre of the social and everyday service, a centre of leisure, transport and logistics (including, but not limited to the wholesale bases supplying groceries to Dudinka and other settlements, no matter how strange it may look), a raw material processing centre (fish and venison). Norilsk is a centre for extreme sports, hunting, fishing and recreational tourism (though underperforming its actual potential). After the perinatal centre construction, Norilsk has a potential to become a large medical centre for all the Northern and Arctic regions of the Krasnoyarsk Territory, provided that the transport system is improved and, in particular, Igarka gets "connected".

In the future, the functions of Norilsk (Norilsk Industrial District) need to be dramatically expanded to make it the key base of the comprehensive exploration of the Northern and Arctic regions of the Krasnoyarsk Territory, scientific (geology, construction technology, environment and nature preservation technologies, agriculture and modern biotechnologies, Arctic medicine), social (especially medical) educational and transport-logistic centre.

For the nearby areas, Norilsk is the closest (and together with Dudinka, the only) point of access to the modern technologies, high-quality medical, social and educational service, as well as the transit supply base. Moreover, Norilsk is a potential point of departure for many touristic routes and a centre of processing the agricultural raw materials. At all that, the development of the exploration base in Norilsk is relevant not only for the surrounding territory but also to the city itself to support its diverse intellectual urban environment and to keep its specialization range broad as it is.

\section{Target milestones}

The implementation of the principles and priorities of the new Northern and Arctic regional policy will be monitored based on four blocks of indicators: social development, economic development, rational resource-use and environment protection, administration improvement. The monitoring is suggested to include over 15 different indicators (see Table 2) developed and approved by the State Statistics Service of the Russian Federation.

The challenge specific for the Krasnoyarsk Territory is the absence of individual statistic reports for the Arctic (the Taymyr and Turukhansk Municipal Districts, Norilsk) and the Northern regions (the Evenkia Mu- 
Table 2. Indicators (target milestones) of the socioeconomic development of the Arctic and Northern regions of the Krasnoyarsk Territory for the period until 2030

\begin{tabular}{|c|c|c|c|}
\hline & $\begin{array}{c}2018 \\
\text { actual }\end{array}$ & $\begin{array}{c}2024 \\
\text { estimated }\end{array}$ & $\begin{array}{c}2030 \\
\text { estimated }\end{array}$ \\
\hline Population for January 01 , thousand people & 438.0 & 435 & 433 \\
\hline Including indigenous population & $16.3(2010)$ & 16.5 & 17.0 \\
\hline Life expectancy at birth & 70.7 & 73.0 & 75.0 \\
\hline Official poverty level, $\%$ & 4.2 & 3.8 & 3.2 \\
\hline $\begin{array}{l}\text { Average official unemployment rate, per cent - } \\
\text { Boundary level for the municipal entities belonging to the North- } \\
\text { ern and Arctic regions of the Krasnoyarsk Territory }\end{array}$ & 3.6 & 3.0 & 2.6 \\
\hline $\begin{array}{l}\text { Infant mortality for } 1000 \text { live birth - } \\
\text { Dispersion of the maximum and minimum values for the munic- } \\
\text { ipal entities of the Northern and Arctic regions, times }\end{array}$ & $\begin{array}{l}5.2 \\
\text { (11 Turukhansky } \\
\text { District } \\
\text { 2.1Norilsk) }\end{array}$ & 3.0 & 2.5 \\
\hline $\begin{array}{l}\text { Total floorspace of the accommodation available per one person, } \\
\text { maximum and minimum values for the municipal entities of the } \\
\text { Northern and Arctic regions, sq.m per person }\end{array}$ & $20-29$ & $23-28$ & $28-31$ \\
\hline $\begin{array}{l}\text { Number of small and medium-sized business entities operating } \\
\text { in the Northern and Arctic regions, units }\end{array}$ & 12385 & 15000 & 17500 \\
\hline $\begin{array}{l}\text { Average rate (without outsourced part-time workers) of staff em- } \\
\text { ployed by microcompanies, small and medium-sized business- } \\
\text { es and individual entrepreneurs in the total employed popula- } \\
\text { tion number (without outsourced part-time workers), per cent: } \\
\text { maximum and minimum values for the municipal entities of the } \\
\text { Northern and Arctic regions }\end{array}$ & $37.8 / 3.4$ & $38.5 / 10.0$ & $39.8 / 14.4$ \\
\hline Volume of imported fuel and lubricants, thousand tons & 91.7 & 90.0 & 82.5 \\
\hline Volume of imported coal, thousand tons & 164.7 & 160.0 & 150.0 \\
\hline Reindeer, including public and private herds, thousand heads & 130.5 & 132.0 & 134.0 \\
\hline $\begin{array}{l}\text { Share of the retrained, requalified municipal officials of the } \\
\text { Northern and Arctic regions of the Krasnoyarsk Territory, per } \\
\text { cent: maximum and minimum values for the municipal entities } \\
\text { of the Northern and Arctic regions }\end{array}$ & $60-4$ & $65-15$ & $70-25$ \\
\hline $\begin{array}{l}\text { Share of the representatives of the indigenous peoples in the ad- } \\
\text { ministration bodies (municipal and regional level) in proportion } \\
\text { to the share of the indigenous peoples in the total population of } \\
\text { the region, per cent - } \\
\text { maximum and minimum values for the municipal entities of the } \\
\text { Northern and Arctic regions of the Krasnoyarsk Territory }\end{array}$ & $27-0.33$ & $33-5$ & $38-11$ \\
\hline
\end{tabular}

nicipal District, Lesosibirsk, Yeniseisk, the Severo-Yeniseisky, Yeniseisky, Boguchansky, Kezhemsky, Motyginsky Municipal Districts) causing the need for collecting input information for every municipal entity, analyzing the social, economic, resource processing and environmental indicators for all the municipalities of the Arctic and the Northern parts of the region.
During the implementation of the Strategy till the year 2030, the actual tendency of decline in the population of the Northern and Arctic regions of the Krasnoyarsk Territory is expected to continue but become less intensive: due to the consistent efforts of the government represented by the federal and regional authorities, the population outflow is supposed to significantly decrease. Against 
the background of the general population decrease, the number of the small-numbered indigenous peoples of the North will insignificantly increase due to the growing birth rate of the indigenous peoples compared to the resettlers. The Northern and Arctic regions of the Territory will reach the average Russian life expectancy level of 75 years by 2030 (today, this indicator in the region remains below the Russian average).

The officially registered poverty level will keep decreasing throughout the forecast period, but the process will accelerate after 2024 due to the effect from the implementation of several large resource extraction projects in the Territory, first of all, in the Taymyr Peninsula. There will be a slight decline in the official unemployment rate, but the informal unemployment will significantly drop as the people desperate to find a job do not register as unemployed and are not accounted by the official statistics. The focused efforts of the regional authorities directed at this category of population can result in obvious positive dynamics in the informal unemployment rate. Another reserve is the unemployment of the small-numbered indigenous peoples of the North. The share of the small-numbered indigenous peoples in the total unemployment rate is known to increase every time the general unemployment situation in the Northern and Arctic region improves. Every new per cent of less unemployment requires more and more efforts to settle the situation with this vulnerable part of the population.

The Northern and Arctic regions of the Krasnoyarsk Territory face a large internal contrast in the infant mortality rates, which currently differ by five times between the prosperous and depressive districts. This is why within the forecast period the authorities are expected to make special efforts not only to reduce the general infant mortality rate but to minimize the gap between the values of the urban and rural areas of the Northern and Arctic regions to 2.5-3 times.

A similar focused policy will be run for the accommodation issues. The current contrast in the available accommodation values of the Arctic and the Northern regions of the Territory are unacceptable, reaching approxi- mately 1.5 times. This value is planned to be improved.

The strategy foresees the growth in the number of the small and medium-sized businesses in the Northern and Arctic regions of the Krasnoyarsk Territory by approximately 1.5 times. The main emphasis will be made again not only to the quantitative growth but to the minimization of difference in the number of people engaged in entrepreneurship between the Arctic and Northern territories; the 12-times' difference we see today will be reduced to three times by the end of the forecast period. The efforts will be made to substitute the imported coal, lubricants and boiler fuel with the locally produced ones. The imported fuel share is planned to be reduced by approximately $10 \%$.

For many natural reasons (increasing excessive overgrazing in the Western part of the Territory by the Yamal border, traditional Taymyr problem of the wild reindeer "splitting off" the she-reindeer from the domestic herds, competition between the reindeer breeding, fishery and hunting within the traditional economy etc.), the increase of the domestic reindeer is expected to be around 4 thousand heads.

In the municipal administration sphere, the number of retrained and requalified officials is expected to significantly grow; the representation of the indigenous peoples in the local (municipal) authority bodies is expected to increase along with the reduction of the intermunicipal contrast of the values.

As for the production values of the nickel, copper, platinum, gold, palladium, oil and gas, strategically important for Russia and essential for the municipal economy, due to the large investment projects run by the local Russian and resource extracting corporations a stable growth is expected. First of all, the investment projects deployed in the Northern and Arctic regions of the Krasnoyarsk Territory in the forecast period will have doubled the gross product of the territory by the year 2030 .

\section{Implementation mechanisms}

The key institutional mechanisms for the implementation of the principles and approaches of the new regional Northern and 
Arctic policy are the enhancement of the current (first of all, the Agency for the Development of the Northern Areas and Support of the Small-Numbered Indigenous Peoples of the Krasnoyarsk Territory) and establishment of the new elements of the regional development institution system (first of all, the three project offices).

The key financial and economic implementation mechanisms in the spheres of investment policy and development of the small and medium-sized businesses in the Northern and Arctic regions of the Territory are: implementation of the public-private partnership projects; involvement of external investment into the economy as a source for the socioeconomic development of the Northern and Arctic regions of the Territory; introduction of the strategic projects and events of the North and Arctic regions of the Krasnoyarsk Territory into the state programmes of the Russian Federation to gain federal financial support; employment of the non-budgetary and federal investment in the new preferential regimes represented by the advanced socioeconomic development territories, the core development areas of the Arctic region of the Russian Federation; cooperation with the federal development institutions and the state corporations to expand the access to bank loans, guarantee products and other financial tools as well as advanced education, information and consultation resources of the federal level etc.

There is a proposal to make a five-year agreement with the Federal Entrepreneurship Development Corporation for the encouragement of the business projects run by the entrepreneurs from the Northern and Arctic regions of the Krasnoyarsk Territory in the sphere of the energy and food security of the local communities to gain additional budgetary sources for the replacement of import and activation of the long-term use of the local sources of food, boiler and furnace fuels. A paragraph on supporting local business initiatives for the food and energy security may be also introduced into the agreements concluded with Rosneft State Corporation, Norilsk Nickel Company, Russian Platinum and other resource corporations active in the Krasnoyarsk Territory.
Another important task in the implementation measures' system is to restore an integrated federal statistics monitoring system which used to operate in the Northern and Arctic regions when they were divided as separate constituent entities of the federation (as the Taymyr and Evenkia Autonomous Okrugs). It will open new opportunities for planning, assessment of the achieved performance values and evaluation of the practical activities of the regional and municipal authorities for the implementation of the new regional policy principles and approach to the Northern and Arctic regions of the Territory.

\section{Conclusion: Future of the North and the Arctic regions \\ of the Krasnoyarsk Territory}

By 2030, the Krasnoyarsk North and Arctic will become a geographic and economic centre of industrialization 2.0 for the entire Russian Arctic due to the simultaneous introduction of a dozen of new resource projects in the Taymyr Peninsula, Evenkia and the northern areas. The leadership of the Krasnoyarsk Territory in the Russian Arctic is ensured by the unprecedented expansion of the explored strategic nation-wide resources (oil, gold, coal, non-ferrous metals etc.). Exploration of the new industrial districts will rely upon the equipment and technologies provided by the Siberian and Krasnoyarsk "Arctic Engineering" plants.

With the restoration of the Yenisei-Northern Sea Route transportation corridor as an essential bridge between the Trans-Siberian railway and the Arctic, introduction of a system of efforts for modernization of the ports of Dikson (with the construction of the deepsea terminals for coal handling), Khatanga and Dudinka, enhancement of the role of Dikson in the updated navigation service for safe river traffic in the Eastern sector of the Russian Arctic, the role played by the Krasnoyarsk Territory in the loading and strengthening the national sovereignty in the Northern Sea Route and the cross-polar (to the North Pole) marine and air spaces will be significantly reinforced.

The so-called "experience economy" represented by the extreme, educating, venture tourism to the Putorana Plateau, the Tunguska 
meteorite site, the geographical centre of Russia and other symbolic locations of the Krasnoyarsk Territory, previously accessible only for the premium-class and informal tours, will gain a true national significance and recognition. The environmentally friendly products from the Krasnoyarsk taiga forest will become a national and universal brand.

Consolidated efforts of the state and businesses will bring a breakthrough in the activities directly associated with the living standards of the people: guaranteed employment, high-quality education and healthcare, safe life. The improvement of the living standards is only possible together with the positive changes in the transport infrastructure of the Krasnoyarsk North, energy efficiency of the northern industries and support from the local businesses, including those related to the food and energy security and comfortization of the local service sector.

The increasing accessibility of the high-qualification healthcare specialists will make a positive impact on the average life expectancy of the Northerners, better medical security of the residents of the remote villages of Taymyr and Evenkia. All these can be achieved only with a persistent and meticulous work to ensure the total $4 \mathrm{G}$ Internet coverage of every village and settlement of the Krasnoyarsk North and Arctic.

At the Siberian Federal University, the Institute of North and Arctic will be established to offer Master's programmes for the specialists committed to work in the Northern territories, as well as representatives of small-numbered indigenous peoples engaged in traditional nature use and intending to develop new forms of entrepreneurship in the Arctic.

The improvement of the living standards of the small-numbered indigenous peoples requires raising the employment rate in the areas of traditional residence of such people, introduction of new investment projects in the traditional residence and activity areas of the small-numbered indigenous peoples and support of the youth initiatives and social activities, ethnographic tourism projects etc.

Innovative ethnopedagogy formats are also proposed for implementation. It is planned to provide resource support for the nomadic daycare facilities and nomadic schools, as well as for the "language nests" of the northern settlements to solve the socialization and education problems faced by children representing small-numbered indigenous peoples. An important aspect of education development and preservation of the ethnic culture is the establishment of the internet portals for the ethnic culture and language studies, development of digital archives of the indigenous peoples, creation of online textbooks, digitalization of literature in ethnic languages and audio records, creation of videogames and intermedia materials for history and culture studies. Advanced education and qualification courses for the development of the ethnographic tourism will be developed, ethnotouristic routes, ethnovillages will be created.

The material and spiritual values exhibited at the ethnovillages will be carefully protected. Special support measures will be envisaged for the traditional ethnic artists, writers, and authors of fiction, non-fiction movies and animation representing small-numbered indigenous peoples of the North.

The common feature of all the activities carried out in different spheres of development of the Northern and Arctic regions of the Krasnoyarsk Territory is the encouragement of innovative thinking, introduction of new technologies and business solutions. To enhance the novelty adaptation and succession process, the "pilot-clones" scheme will be used, i.e. a pattern successfully trialled at the pilot platform of one village, mineral deposit, or community, is adopted to many other similar objects.

\section{References}

Audretsch, D.B., Thurik, A.R. (2001). What's New about the New Economy? Sources of Growth in the Managed and Entrepreneurial Economies. In Industrial and Corporate Change, 10 (1), 1, $267-315$. DOI: $10.1093 /$ icc/10.1.267 
Anatolii G. Tsykalov, Ruslan V. Goncharov... Main Principles of the Strategy of Socioeconomic Development...

Gosudarstvennyy doklad "O sostoianii okruzhaiushchey sredy v Krasnoiarskom krae" za 2017 god [State report "On the State of the Environment in the Krasnoyarsk Territory" for 2017]. Available at: http:// mpr.krskstate.ru/dat/File/3/doklad\%202017..pdf

Hausmann, R., Rodrik, D (2002). Economic development as self-discovery. NBER Working Paper Series. No. 8952 (May). 44 p.

Herrschell, T. (2012). Regionalisation and marginalization: bridging old and new divisions in regional governance. In Regional development in Nothern Europe. Peripherality, marginality and border issues. Routledge, 30-48.

Huskey, L. (1987). Import Substitution in Frontier Regions. In: Developing America's Northern Frontier. Ed. by Th. Lane. Boston: University Press of America, 47-61.

Koptseva, N.P. (2017). Ekspertnaia otsenka ekologicheskoy situatsii, kharakternoy dlia korennykh malochislennykh narodov Sibirskoy Arktiki (na materiale Krasnoiarskogo kraia) [Expert Assessment of the Environmental Situation Specific for the Small-Numbered Indigenous Peoples of the Siberian Arctic (Based on the Krasnoyarsk Territory)]. In Ekologiia cheloveka [Human Ecology], 6, 30-35.

Korytnyy, L.M., Tulukhonov, A.K., ed. (2016). Vostochnaia Sibir' [East Siberia], Vol. 6 In Geografiia Sibiri v nachale XXI veka: $v 6$ tomakh [Geography of Siberia in the Early of 21th Century in 6 Volumes] (ed. By V. M. Pliusnin). Novosibirsk, Geo. 392 p.

Kosmachev, Kirill (1974). Pionernoe osvoenie taygi (ekonomiko-geograficheskie problemy) [Pioneer development of the taiga forest zone (economic and geographical problems)], Novosibirsk: Nauka, $143 \mathrm{p}$.

Krasnoyarskstat: Database of indicators of municipalities. Available at: http://www.krasstat.gks.ru/ wps/wcm/connect/rosstat_ts/krasstat/ru/municipal_statistics/krsnMstat/; https://krasstat.gks.ru/storage/ mediabank/Перечень\%20показателей\%202020.docx

Maklakov, K.V., Malygina, N.V. (2016). Sravnitel'nyy analiz vneshnikh faktorov dlia taymyrskoy populiatsii dikogo severnogo olenia [Comparative Analysis of External Factors for the Taymyr Wild Reindeer Population]. In Sibirskiy ekologicheskiy zhurnal [Siberian Environmental Journal], 23, 1, 81-93. DOI: 10.15372/SEJ20160109

Maksimova, I.E., Klitsenko, Iu.V. (2012). "Indeytsy Sibiri”: evenki v sovetskikh igrovykh fil'makh 1920-1930 gg. ["The Indians of Siberia": Evenki in Soviet fiction films of the 1920s-1930s]. In Sibirskaia zaimka [Siberian Zaimka]. Available at: http://zaimka.ru/maksimova-evenki/

Malov, V.Iu. ed. (2014). Mark Konstantinovich Bandman. Izbrannyye trudy i prodolzheniye nachatogo [Mark Konstantinovich Bandman: Selected Works and Continuation of the Started]. Novosibirsk: Institute of Economics and Industrial Engineering of the Siberian Branch of the Russian Academy of Sciences. 448 p.

Pelyasov, A.N. (2017). Siberia: in Search of New Model of Development. In Journal of Siberian Federal University. Humanities \& social sciences, 11 (10), 1754-1778.

Petrov, A.N. \& BurnSilver, Shauna \& Chapin III, F Stuart \& Fondahl, G. \& Graybill, Jessica \& Stephen, Kathrin \& Nilsson, Annika \& Riedlsperger, R. \& Schweitzer, Peter (2017). Arctic Sustainability Research: Past, Present and Future. DOI: 10.4324/9781315109954

Rodrik, D. (2004). Industrial Policy for the Twenty-First Century. Harvard University 2004. 57 p.

Sartakov, V.V., ed. (1985). Problemy sovershenstvovaniia obraza zhizni v usloviiakh Severa [Problems of Lifestyle Improvement in the North]. Krasnoyarsk: Krasnoyarsk University Press. 154 p.

Semenova, A.R., Popel'nitskaia, I.M. (2017). Use of Panel Data for Assessing Socio-Economic Situation in the Northern Regions of Krasnoyarsk Territory. In Journal of Siberian Federal University. Humanities \& Social Sciences, 12 (10), 1905-1915.

Shadrin, A.I., Larionova, L.Iu. (2019). Novaia ekonomicheskaia i sotsial'naia geografiia Krasnoiarskogo kraia: uchebnoe posobie [New Economic and Social Geography of the Krasnoyarsk Territory: textbook]. Krasnoyarsk: Astafiev Krasnoyarks State Pedagogical University. 209 p.

Slavin, S.V. (1961). Promyshlennoe i transportnoe osvoenie Severa SSSR [Industrial and Transport Development of the North of USSR]. Moscow: Ekonomizdat. 302 p.

Taylor, A., Carson, D.B., Ensign, P.C., Huskey, L., Rasmussen, R.O., Saxinger, G., editors (2016). Settlement at the Edge. Remote Human Settlements in Developed Nations. Edward Elgar Publishing: Cheltenham, UK, Northampton, MA, USA. 450 p. 
Zamiatina, N.Yu., Pelyasov, A.N. (2013). Rossiia, kotoruiu my obreli: issleduia prostranstvo na mikrourovne [Russia We Gained: Exploring the Space at the Micro Level], Moscow, Novyy Khronograf, 544 p.

\title{
Контуры стратегии социально-экономического развития северных и арктических территорий Красноярского края
}

\author{
А.Г. Цыкалов ${ }^{\mathrm{a}}$ Р.В. Гончаров ${ }^{6}$ Н.П. Копцевав, \\ А.Н. Пилясов ${ }^{r, \mu}$, А.В. Потураеваг,, Н.Ю. Замятинаг, \\ аПравительство Красноярского края \\ Российская Федераџия, Красноярск \\ ${ }^{\sigma}$ Научный исследовательский университет «Высшая школа экономики» \\ Российская Федерачия, Москва \\ ${ }^{8}$ Сибирский федеральный университет \\ Российская Федерация, Красноярск \\ 'Институт регионального консалтинга \\ Российская Федерачия, Москва \\ ${ }^{\partial}$ Московский государственный университет им. М.В. Ломоносова \\ Российская Федерация, Москва
}

\begin{abstract}
Аннотация. Предлагаются новые принципы и подходы к развитию арктических и северных территорий Красноярского края. Основной идеологией новой региональной политики края должно стать активное поощрение саморазвития, предпринимательской инициативы, обеспечение продовольственной и энергетической безопасности местных сообществ Севера и Арктики. Новая региональная политика должна иметь территориально дифференцированный характер исходя из наличия шести фундаментально различных по транспортно-экономическим условиям территорий. Приоритеты новой политики направлены на всемерное уменьшение внутренних контрастов развития между отдельными муниципальными образованиями Севера и Арктики края. Особые надежды связываются с «тотальным» внедрением инноваций в доставку критически важных услуг и товарных групп в удаленные города и поселки края. Для реализации этой идеологии предлагается создать три проектных офиса - «человек», «поселение», «территория», призванных обеспечить эффекты синергии при взаимодействии власти, крупного и малого бизнеса и структур гражданского общества во имя повышения качества жизни каждого жителя северных и арктических территорий края. Каждый из проектных офисов ориентирован на решение проблем соответствующего масштабного уровня: отдельного человека - жителя края, населенных пунктов и северных территорий в целом. Предполагается, что в результате предлагаемых мер Красноярский край сумеет в 2030 году вернуть те позиции лидера в освоении российской Арктики, которые он занимал на протяжении первых советских десятилетий.
\end{abstract}

Ключевые слова: экономическое развитие, северные и арктические территории Красноярского края, инновационная система, проектные офисы.

Научная специальность: 24.00.00 - культурология. 